Cornell University Law School

Scholarship@Cornell Law: A Digital Repository

$4-2016$

\title{
The 2015 Changes to the Federal Rules Matter for Your Patent Case and Tech Business: Getting in the Courthouse Door Just Got Tougher
}

Matthew D'Amore

Cornell Tech, mmd28@cornell.edu

Follow this and additional works at: http://scholarship.law.cornell.edu/facpub

Part of the Civil Procedure Commons, and the Intellectual Property Law Commons

\section{Recommended Citation}

D'Amore, Matthew, "The 2015 Changes to the Federal Rules Matter for Your Patent Case and Tech Business: Getting in the Courthouse Door Just Got Tougher," MoFo IP Newsletter, April 2016

This Article is brought to you for free and open access by the Faculty Scholarship at Scholarship@Cornell Law: A Digital Repository. It has been accepted for inclusion in Cornell Law Faculty Publications by an authorized administrator of Scholarship@Cornell Law: A Digital Repository. For more information, please contact jmp8@cornell.edu. 

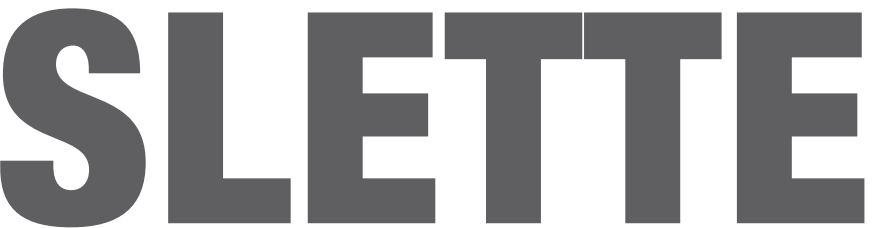

\section{IN THIS ISSUE}

The 2015 Changes to the Federal Rules Matter for Your Patent Case and Tech Business: Getting in the Courthouse Door Just Got Tougher

Page 1

Will the Supreme Court Put the Brakes on the IPR Trend? Cuozzo Speed Tech., LLC v. Lee

Page 4

JFTC Wields Antitrust Law to Enforce FRAND Obligations of Standard Essential Patents

Page 6

Landmark Decision of German Federal Court of Justice on Blocking of Copyright-infringing Websites Page 6

First German Decisions Applying the ECJ's Huawei v. ZTE Framework on Injunctions for Standard Essential Patents

Page 8

\section{EDITORS}

Rachel Krevans

rkrevans@mofo.com

Richard S.J. Hung

rhung@mofo.com

Nathan Sabri

nsabri@mofo.com

\section{CONTRIBUTORS}

$\begin{array}{ll}\text { Matt D’Amore } & \text { Brian Matsui } \\ \text { mdamore@mofo.com } & \text { bmatsui@mofo.com } \\ \text { Johannes Hieronymi } & \text { Rufus Pichler } \\ \text { jhieronymi@mofo.com } & \text { rpichler@mofo.com } \\ \text { Holger Kastler } & \text { Louise Stoupe } \\ \text { hkastler@mofo.com } & \text { lstoupe@mofo.com } \\ \text { Matthew Kreeger } & \text { Chihiro Tomioka } \\ \text { mkreeger@mofo.com } & \text { ctomioka@moro.com } \\ \text { Seth Lloyd } & \text { Christoph Wagner } \\ \text { slloyd@mofo.com } & \text { cwagner@mofo.com }\end{array}$

MOR R I S O N

\section{THE 2015 CHANGES TO THE FEDERAL RULES MATTER FOR YOUR PATENT CASE AND TECH BUSINESS: GETTING IN THE COURTHOUSE DOOR JUST GOT TOUGHER}

\section{By Matthew D’Amore}

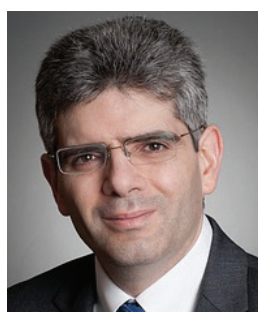

It used to be that a complaint for patent infringement would survive a motion to dismiss if it included: "1) an allegation of jurisdiction; 2) a statement that the plaintiff owns the patent; 3 ) a statement that defendant has been infringing the patent 'by making, selling, and using [the device] embodying the patent'; 4) a statement that the plaintiff has given the defendant notice of its infringement; and 5) a demand for an injunction and damages." McZeal v. Sprint Nextel Corp., 501 F.3d 1354, 1356-57 (Fed. Cir. 2007). So long as you followed these elements set forth in Form 18 found in the Federal Rules of Civil Procedure, your complaint was likely to pass muster. See Id.; K-Tech Telecomms, Inc. v. Time Warner Cable, 714 F.3d 1277, 1283 (Fed. Cir. 2013), cert. denied, 134 S. Ct. 1026 (2014).

But the December 2015 amendments to the Federal Rules of Civil Procedure "abrogated" the forms in their entirety. What does that mean for you? Read on.

Below, we'll give a bit of history on how we got here, and then offer some practical tips depending on which side of the "v" you're on.

\section{A. Patent Cases Are (Now) Just Like Every Other Case}

Rule 84 of the Federal Rules of Civil Procedure introduced a series of forms that became part of the rulebook. It provided that " $[t]$ he forms in the Appendix suffice $[d]$ under these rules and illustrate[d] the simplicity and brevity that these rules contemplate.” Fed. R. Civ. P. 84 (2007) (emphasis added). Form 18 (previously Form 16) identified the short set of five simple allegations for pleading patent infringement set out above. See McZeal, 501 F.3d at 1356-57.

Of course, in 2007 and 2009, the Supreme Court set out new standards for what a federal court complaint must contain. See Ashcroft v. Iqbal, 556 U.S. 662, 129 S. Ct. 1937 (2009); Bell Atl. Corp. v. Twombly, 550 U.S. 544, 127 S. Ct. 1955 (2007). Under Iqbal:

continued on page 2 
To survive a motion to dismiss, a complaint must contain sufficient factual matter, accepted as true, to "state a claim to relief that is plausible on its face." A claim has facial plausibility when the plaintiff pleads factual content that allows the court to draw the reasonable inference that the defendant is liable for the misconduct alleged.

Iqbal, 556 U.S. at 678 (citing and quoting Twombly). The Court also made clear that " $[\mathrm{t}]$ hreadbare recitals of the elements of a cause of action, supported by mere conclusory statements, do not suffice." Id.

It would not be a stretch to call the allegations of Form 18 "threadbare," as they fill all of four paragraphs. In a trio of decisions between 2007 and 2013, however, the Federal Circuit confirmed that it would continue to look to the form for what sufficed to state a claim. See K-Tech, 714 F.3d at 1283 ("[A] proper use of a form contained in the Appendix of Forms effectively immunizes a claimant from attack regarding the sufficiency of the pleading... [T]o the extent any conflict exists between Twombly (and its progeny) and the Forms regarding pleadings requirements, the Forms control."); $R+L$ Carriers, Inc. $v$. DriverTech LLC (In re Bill of Lading Transmission and Processing Sys. Patent Litig.), 681 F.3d 1323 (Fed. Cir. 2012) ("R+L Carriers"); McZeal, 501 F.3d at 1356-57.

Eliminating the form removes the foundation from these decisions. The question then is whether they stand on their own. Here's what the Advisory Committee Notes say about the deletion of Rule 84, which included the forms:

Rule 84 was adopted when the Civil Rules were established in 1938 "to indicate, subject to the provisions of these rules, the simplicity and brevity of statement which the rules contemplate." The purpose of providing illustrations for the rules, although useful when the rules were adopted, has been fulfilled. Accordingly, recognizing that there are many excellent alternative sources for forms, including the website of the Administrative Office of the United States Courts, the websites of many district courts, and local law libraries that contain many commercially published forms, Rule 84 and the Appendix of Forms are no longer necessary and have been abrogated. The abrogation of Rule 84 does not alter existing pleading standards or otherwise change the requirements of Civil Rule 8.

Fed. R. Civ. P. 84 (Committee Notes on Rules - 2015 Amendment). Interestingly, the committee notes ignore the part of the rule stating that the forms "suffice under these rules," on which the Federal Circuit had relied. As a result, the notes give zero guidance to patent litigants suddenly bereft of the safe harbor cited by the appellate court.
So, now what?

\section{B. Tips for Getting in the Door and Staying There}

\section{Signs that Point the Way}

Judge Dyk's partial dissent in McZeal provides one interpretation of what Twombly and Iqbal might require in patent cases. Seemingly prepared to tear up the form based on Twombly, Judge Dyk argued that "[t]he form fails to state which claims are asserted and which features of the accused device are alleged to infringe the limitations of those claims." 501 F.3d at 1360 (Dyk, J., dissenting in part). And for a claim under the doctrine of equivalents, Judge Dyk also argued that a complaint would need to "specify which limitations are literally infringed and which are infringed by equivalent [and], as to the limitations alleged to be infringed by the doctrine of equivalents, how the accused product is insubstantially different from the patented devices." Id.

$R+L$ Carriers also provided guidance on what is needed for a claim of contributory and induced infringement, and this sheds light on direct infringement as well. According to the Federal Circuit, "[t]o state a claim for contributory infringement, therefore, a plaintiff must, among other things, plead facts that allow an inference that the components sold or offered for sale have no substantial non-infringing uses." 681 F.3d at 1337 . The $R+L$ plaintiff, unfortunately, filed complaints that "actually make clear on their face that [the accused] products $d o$ have substantial non-infringing uses" and so pleaded itself out of court on that count. Id. at 1339.

Similarly, for induced infringement, the Federal Circuit held that "complaints must contain facts plausibly showing that [the defendants] specifically intended their customers to infringe the [] patent and knew that the customer's acts constituted infringement." Id. As the court observed:

This determination is, of course, case specific. In some circumstances, failure to allege facts that plausibly suggest a specific element or elements of a claim have been practiced may be fatal in the context of a motion to dismiss. Or, as with $\mathrm{R}+$ L's contributory infringement claims, facts may be pled affirmatively which defeat a claim on its face. But, there is no requirement that the facts alleged mimic the precise language used in a claim; what is necessary is that facts, when considered in their entirety and in context, lead to the common sense conclusion that a patented method is being practiced.

Id. at 1342-43. These points equally apply to pleading a claim of direct infringement without the benefit of the form and suggest a flexible, fact-dependent approach. 
Furthermore, even before the change in the rules, some courts required additional specificity for claims of direct infringement. For example, a complaint for patent infringement was dismissed in Macronix Int'l Co. v. Spansion Inc., where (a) "the claims for literal infringement $\mathrm{d}[\mathrm{id}]$ not allege how the offending products [infringe] the claims recited in the [complaint]"; (b) the complaint "simply allege[d] that each element of a cited claim is infringed and then parroted the claim language for each element"; (c) the complaint "fail[ed] adequately to allege infringement under the doctrine of equivalents because [it] merely asserts liability under that doctrine in a bare bones, conclusory form;" and (d) "it [was] not even clear from the FAC what is alleged to be literally infringed and what was alleged to be infringed by equivalents." $4 \mathrm{~F}$. Supp. 3d 797, 804 (E.D. Va. 2014). The court noted that "the showing need not be made in detail[,]... but must be made." Id. at 804 n.4.

\section{The Form is Dead; Long Live the Form?}

Despite Macronix, there's an argument to be made that notice pleading according to Form 18 still suffices. The argument goes like this: Former Rule 84 stated that the form "suffice[d]" under the rules, and the Advisory Committee itself stated that removing the form did not change what was and was not an acceptable pleading. Fed. R. Civ. P. 84 (2015 Advisory Committee Note) ("The abrogation of Rule 84 does not alter existing pleading standards or otherwise change the requirements of Civil Rule 8."). Prior to the abrogation of the form, a panel of the Federal Circuit observed, without deciding, that it is at least possible that "[a] complaint containing just enough information to satisfy a governing form may well be sufficient under Twombly and Iqbal." K-Tech, 714 F.3d at 1284. Even the Supreme Court in Twombly noted that a change to a "heightened" pleading standard beyond Rule 8 would require amendment to the Federal Rules. See Twombly, 550 U.S. at 569 n.14. In short, while the form is gone, one could argue that it was merely exemplary of what constitutes "a short, plain statement of the claim showing that the pleader is entitled to relief" (Fed. R. Civ. P. 8(a)(2)) and thus that the Federal Circuit jurisprudence that accepted such statements remains good law.

At least one district court has adopted this approach, finding a complaint sufficient where it contained the basic allegations set out in K-Tech and McZeal:

Though Form 18 and Rule 84 were abrogated from the Federal Rules of Civil Procedure as of December 1, 2015, the Advisory Committee note associated with this change directly states, "The abrogation of Rule 84 does not alter existing pleading standards or otherwise change the requirements of Civil Rule 8.” Fed. R.

Civ. P. 84 (2015 Advisory Committee Note). Thus, the
Court refers to previously existing standards in ruling upon the instant Motion.

Hologram USA, Inc. v. Pulse Evolution Corp., No. 2:14-0772-GMN-NJK, 2016 WL 199417, at *2 n.1 (D. Nev. Jan. 15, 2016); compare with Zoetis LLC $v$. Roadrunner Pharmacy, Inc., No. CV 15-3193, 2016 WL 755622 , at $* 5$ (D.N.J. Feb. 25, 2016) (finding claims of direct and indirect patent infringement failed to include information required by Form 18 and $R+L$ Carriers). However appealing, this approach risks running afoul of Judge Dyk's partial dissent in McZeal and the suggestion in $R+L$ Carriers that Twombly and Iqbal must be considered when the form is not available.

\section{Pleading Plausibility}

We don't know yet exactly what degree of specificity the Federal Circuit will require. We'll be learning what not to do as the case law evolves, but the cases provide at least some suggestions for a complaint to have the best chance of surviving a motion to dismiss:

- Do your pre-filing investigation. Not only is it a good idea, it's the law.

- Identify asserted claims. (It remains to be seen whether phrasing like "at least claims 1,5 and 7 " or "including but not limited to claims 1,5 and 7" will keep other claims in play.)

- Identify accused products with as much specificity as possible. If accusing a class of products, provide some reason to infer that the class works in the same way.

- Provide a claim chart comparing the accused device to the claim language, using facts rather than conclusory assertions.

- Specify limitations met by the doctrine of equivalents, including facts supporting the claim of insubstantial difference.

- Plead specific facts supporting an inference of induced, contributory or willful infringement.

This is obviously a tall order. Is it all necessary? What we can say is that, just like the enormous growth in motions to dismiss brought under Section 101 after Bilskiv. Kappos, 561 U.S. 593 (2010) and Alice Corp. Pty. Ltd. v. CLS Bank Int'l, 134 S. Ct. 2347 (2014), the death of the form is sure to spark a growth in Rule 12(b)(6) motions to challenge pleadings seemingly lacking in one way or another. A detailed and well-pleaded complaint is the surest way to overcome such a motion or avoid it in the first place. 


\section{Tips for Slamming the Door Shut (or Just Leaving a Narrow Gap...)}

If you're on the other side of the "v," considering a motion to dismiss or a motion for a more definite statement (Fed. R. Civ. P. 12(b)(6), Rule 12(e)) should be one of the first things on your list to consider. And even if you can't knock out the entire case, you may be able to take out part of it. Here are some possible targets:

- Look for conclusory assertions that component $\mathrm{x}$ meets claim element y. Even if claim charts are provided, conclusory recitations that just repeat claim language should be viewed skeptically.

- Watch for allegations against one product that are generalized for other similar products. Are the facts alleged sufficient to make that generalization plausible?

- Look for gross mismatches between the number of claims identified or charted and the number of claims in the patents. An allegation that "at least" claim 1 is infringed may provide little notice for a patent with sixty claims.

- Get specific regarding indirect infringement. Particularly for complaints that only allege indirect infringement (for example, because the direct infringer is a customer, mobile user, patient, or physician), the additional elements needed for pleading indirect infringement (e.g., knowledge, lack of substantial noninfringing uses) may be weak points.

- Consider whether to target boilerplate claims of willful infringement.

The cost-effectiveness of a motion to dismiss in the path to a successful result of the case also should also be considered. It may not matter that claims of contributory infringement are eliminated at the pleading stage if induced infringement will remain; it may be more costeffective to take both out at summary judgment later in the case. Alternatively, a motion to dismiss or for a more definite statement may be useful to narrow the case to a certain set of claims or products if discovery can be limited to what remains.

While the district courts may take varying approaches based on the facts before them (compare Macronix with Hologram USA) and Congress may add further complexity (by passing legislation that imposes new patent pleading standards), in the meantime the betting is that pleading a patent case is more difficult than it used to be and far more likely to be challenged.

\section{WILL THE SUPREME COURT PUT THE BRAKES ON THE IPR TREND? CUOZZO SPEED TECH., LLC V. LEE}

By Matthew Kreeger, Brian Matsui, and Seth Lloyd
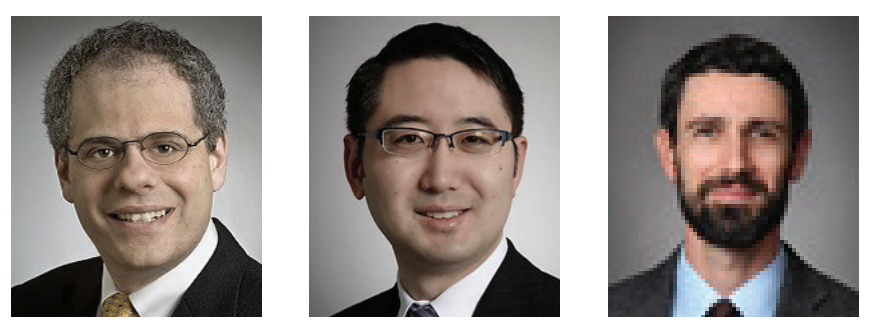

Not so fast: the United States Supreme Court is set to review the America Invents Act's ("AIA") fast-track inter partes review ("IPR") process. On January 15, 2016, the Supreme Court granted certiorari in Cuozzo Speed Technologies, LLCv. Lee, No. 15-446, to address two questions: (1) whether the United States Patent and Trademark Office ("PTO") acted within its rulemaking authority by adopting the rule that patent claims be given their "broadest reasonable interpretation" during IPR proceedings; and (2) whether a party may challenge, on appeal to the Federal Circuit, any part of the PTO's decision to institute an IPR.

Whatever the Supreme Court decides, patent owners and potential challengers alike should watch Cuozzo carefully. Challenging a patent's validity in IPRs has become a mainstay whenever a party is sued for patent infringement in district court. Defendants view IPRs as a cost-effective, efficient alternative to often lengthy district court litigation, even though the AIA's estoppel provisions require accused infringers to make certain invalidity challenges in only one forum or the other. How the Supreme Court answers these two questions could make IPRs less favorable to patent challengers or more like district court litigation, either of which may lead parties to rethink when it makes sense to bring an IPR. The Court will hear argument on April 25, 2016, and should issue its decision before the Supreme Court's summer recess in late June/early July this year.

\section{THE BROADEST REASONABLE INTERPRETATION STANDARD}

The first issue involves the PTO's long-established practice of construing claims in a patent or application according to their "broadest reasonable interpretation" when determining the claim's patentability. The broadest reasonable interpretation arguably produces broader constructions than the standard federal courts apply when construing claims in litigation. This difference has been justified in part because, during PTO proceedings, a patent owner or applicant generally has the opportunity to amend its claims to avoid a potentially 